Turkish Online Journal of Qualitative Inquiry (TOJQI)

Volume 9, Issue 3, July 2018: 240-261 / Cilt 9, Sayı 3, Temmuz 2018: 240-261

DOI: $10.17569 /$ tojqi.322997

Research Article / Araştırma Makalesi

\title{
Metaphoric Perceptions of Middle School Students About the Concept of Secularism ${ }^{1}$
}

\author{
Muzaffer Çatak ${ }^{2}$
}

\begin{abstract}
Social studies is an important course in middle schools. Social studies, however, varies in scope as social studies benefit from social sciences' knowledge production. Social studies include social sciences' topics as well as such topics as social responsibility, socialization, social relations. These topics are directly or indirectly linked to the concept of secularism. The concept of secularism influences and shapes the political, social, military and even economic structures of a given country. The purpose of this study, by way of metaphor, is to examine the concept of secularism that students learn in social studies courses. In this study, the descriptive survey model was used and the content analysis was used in determining the categories and themes. The study group consists of students from two middle schools located in Siirt province center. The prepared forms were applied to 155 students. In determining the sample, convenience sampling was utilized from non-random sampling methods. As a result, when metaphors, categories and category ratios related to secularism are examined and they were found as $35 \%$ socially and culturally, $25 \%$ politically and administratively, $16 \%$ religiously, $13 \%$ legally and $11 \%$ in the sense of belonging. Considering the ratios, it is seen that they are considered in terms of social and cultural the most and in terms of legal and sense of belonging the least. The categorization of the secularism concept by the students at a high rate socially and culturally and politically and administratively is assessed as positive by considering the definition and structure of the concept.
\end{abstract}

Keywords: Secularism; social studies, metaphor, qualitative research.

\footnotetext{
${ }^{1}$ This study is a developed and modified form of the report presented at the International Symposium on Social Studies Education (USBES VI) held during 4-6 May, 2017 at Anadolu University.

2 Asst.Prof.Dr., Siirt University, Faculty of Education, Department of Social Studies and Turkish Education, mucaffer@hotmail.com, https://orcid.org/0000-0002-7059-7979
}

Received: 21.06.2017 Accepted: 31.07.2018 


\title{
Ortaokul Öğrencilerinin Laiklik Kavramına İlişkin Metaforik Algılari
}

\begin{abstract}
$\ddot{\mathbf{O} z}$
Sosyal bilgiler mihver bir ders olduğundan ortaokullarda önemli bir yeri vardır. Bununla beraber sosyal bilgiler, sosyal bilimlerin bilgi üretiminden faydalandığ 1 için kapsam bakımından çeşitlilik göstermektedir. Sosyal bilgiler, sosyal bilimlerin yanında öğrencilerin toplumsal sorumluluk, sosyalleşme, toplumsal ilişkiler gibi unsurlara da önem vermektedir. Bu unsurlar, laiklik kavramı ile doğrudan veya dolaylı olarak birbirleriyle bağlantılıdır. Bu kavram bir ülkenin baştan ayağa siyasi, sosyal, askeri hatta ekonomik olarak neredeyse bütün yapılarını etkilemekte ve şekillendirmektedir. Bu çalışmanın amacı; öğrencilerin, sosyal bilgiler dersi ile edindikleri laiklik kavramını, metafor yolu ile nasıl algıladıklarını ortaya koyarak incelemektir. Bu araştırmada tarama modeli kullanılmış olup, kategorilerin ve temaların belirlenmesinde ise içerik analizinden faydalanılmıştır. Çalışma grubunu, Siirt il merkezinde yer alan iki ortaokulun öğrencileri oluşturmaktadır. Hazırlanmış olan form 155 öğrenciye uygulanmıştır. Örneklemin belirlenmesinde seçkisiz olmayan örnekleme yöntemlerinden uygun örnekleme kullanılmıştır. Sonuç olarak, laiklikle ilgili oluşturulan metaforlar, kategoriler ve kategorilerin oranları incelendiğinde; sosyal ve kültürel açıdan \%35, siyasi ve idari açıdan $\% 25$, dini açıdan \%16, hukuki açıdan \%13, aitlik açısından \%11 olduğu görülmektedir. Oranlara bakıldığında en fazla sosyal- kültürel ile siyasi - idari açıdan ele alındığı, en az ise hukuki ve aitlik açısından ele alındığı görülmektedir. Öğrencilerin laiklik kavramını sosyal- kültürel ve siyasi- idari açıdan yüksek oranda kategorileştirmesi, kavramın tanımı ve yapısı göz önünde bulundurulduğunda olumlu olarak değerlendirilmektedir.
\end{abstract}

Anahtar Sözcükler: Laiklik, sosyal bilgiler; metafor; nitel araştırma. 


\section{Introduction}

The root of the word secularism is the adjective 'laikos' in the ancient Greek and the word 'laos' meaning 'people, crowd, mass'. Hence 'laikos' means 'of public, crowd, mass'. With the spread of Christianity, the people involved in the church were called 'derici' and the believing community was called 'iaici' in Latin. This word entered Turkish during the Constitutionalism Period first and was translated to Turkish as 'ladini'. The word ladini means non-religious (Dinçkol, 2002). In another resource, secularism: 'laikos' originates from Latin 'laicus' and means dealing with world affairs as separate from religious affairs and religious authority. In the legal sense, secularism is the separation of the state and religious affairs and the impartiality of the state for attaining liberty of conscience. In other words, secularism is the situation where the state does not stand between God and his servants and the religion does not interfere with the state affairs (Saray, 2006). When secularism is conceived as a triangle, preventing the religious guardianship of state, institutions constitute one side of the triangle. The second side of the triangle, when pointing to the right or the freedom to believe and not to believe in the individual and social belief, while the last edge of the triangle expresses the equality of different religions and non-religious beliefs by the law (Albayrak, 2015).

Democracy in secularism comprises of fundamental attributes including tolerance, equity, and liberty (Özturanl1, 1999). In this context, it is clear that secularism is a crucial factor for the progress of the country securely towards modern civilization (Akgün, 2006). Tolerance is needed for the progress and development of a country and this can only be attained with the principle of secularism. Tolerance, which exists in the nature of Turkish people and Islam's core, directly harmonizes with the sentiment of respecting the thoughts and believes of others. Considering the history of Turkish states, the people of foreign origin living there maintained their own language, religion and culture in content (Saray, 2006).

In France, with the law of 1905, religion and the state separated from each other by certain lines. The state did not finance religious services and abandoned these services to religious societies. In the French Constitution, the "secular" phrase, which states the nature of the state, has been included since 1946 (Gişi, 2015). Starting from the 1920s in Turkey, a secular 
republic project has been implemented based on the French model. Despite secularism in Turkey took France as an example, it does not simulate secularism practiced in France substantially. It is advocated that France separated the state and religion fundamentally and Turkey keeps religion under control (Kahraman, 2008). Turkey, positive and/or negative additions, secularism has become a proper state system to its cultural code (Dağc1 \& Dal, 2014).

Considering the secularism concept in the constitutions formed after the establishment of the Grand National Assembly of Turkey, secularism was not discussed in 1921 Constitution and the provision that the state religion was Islam was added with the amendments made on October 29, 1923. Though there were provisions against secularism in 1924 Constitution, these provisions were removed with the amendment made in 1928. In this Constitution, the secularism term was used once and the way for the secularization of the new Turkish State was paved. The secularism term took place 7 times in 1961 Constitution. The term was used as a component of national, democratic and social state in general. Hence, it was a powerful constitution as far as the secularism was concerned. In 1982 Constitution, secularism was emphasized more. Secularism was used 10 times including the initial and provisional provisions and it was expressed as a part of democratic republic in general (Ertan, 2007). Secularism is a psycho-social phenomenon (Paker \& Cesur, 2013), characterized by an ideological polarization in one direction and the examination of the existing relations between groups. The concept of secularism has become as a political material by political parties and different extremities rather than human rights, freedom of religion and belief in the agenda of Turkey. As a consequence of anti-Islam, Islamophobia and psychological pressure and ethnic nationalism which in developed democratic countries such as USA and Europe, the perception and attitudes of people in different circles towards secularism have become controversial today. The concept of secularism remains to be current as a political issue in Turkey frequently in discussions. Even in the developed democratic countries, the perceptions and attitudes of people about the secularism concept turned out to be discussed today in the political or social relationships. Whereas the concept of secularism is regarded to be virtually equal to atheism by some sections of the citizens of the Republic of Turkey, it is the foundation of the values for some sections and it is in the central position of politics for some others. The resolution of these extremists will be possible by the gaining and shaping of this knowledge correctly by the students in their minds. 
Social studies teaching, which is the lead of this core class, is a duty with the highest professional and conscious responsibility in terms of teaching the values and crucial concepts for the country. Social studies teachers can ensure various interpretations of the concept of secularism by the students as well as learning of the concept objectively. In this context, it is clear how important the social studies teachers are for becoming a good citizen even though only a concept.

\section{Social Studies Lesson and The Concept Secularism}

Considering the social studies program, it is seen that 160 concepts were used in the $4^{\text {th }}$ grade through the $7^{\text {th }}$ grade. Considering the concept of secularity on the class basis, there is no secularity concept in the $4^{\text {th }}$-grade social studies class. Social studies are taught at the beginners level in the $5^{\text {th }}$ and $6 y$ grades. In the $7^{\text {th }}$-grade social studies class, on the other hand, this concept is taught by social studies teachers at the development level (Bilgili, 2016). The concept of secularism is taught at the reinforcement level by social studies teachers in the textbook of Turkey Republic revolution history and Kemalism.

In the academic year 2017-2018, the fifth-grade textbook used in the social studies class, the sixth and seventh-grade social studies and the eighth- grade Turkish Republic reforming history and Kemalism teacher guidebooks have been examined in terms of secularism. When the fifth-grade social studies textbook (Evirgen et al. 2017) is evaluated in this respect, secularism must be given at the beginners level to the fifth-grade students, but it is seen that the concept of secularism is not included in the book of this course. The removal of the fifthgrade teacher's guidebook reduces the chances of students facing the concept of secularism.

When the concept of secularism is examined in the sixth grade social studies teacher manual (Karakaya et al. 2017), the learning field: power, management and society; it is seen that this concept has passed in three different places within the topic of "The Adventure of Democracy" which is the sixth unit in the unit. The subjects taught here to take part in the constitution of secularism and the abolition of the caliphate, the state structure of the Republic of Turkey and the Unification of Education Law. As it is known, in the 5th and 6th grade, the concept of secularism is given to students at the beginners level. Without 
introducing the concept of secularism directly in the fifth-grade textbook, entering the abovementioned topics in the sixth-grade textbook will definitely make the cognitive perception of the students difficult. In the sixth grade book, the concept of secularism is given as a gap filling. This concept is given in accordance with the beginners level.

It is seen that the concept of secularism is repeated nine times in the seventh-grade social studies teacher guidebook (Unal et al). When they are assessed in general, the field of learning is: science, technology, and society; the unit is "science in time" and it is seen that the concept of secularism passed twice in this unit. The concept of secularism is repeated 6 times in the "living democracy" unit within learning area the power, government and society. In the workbook, it is seen that the concept of secularism is between the test items, but the test cannot be related to secularism and this workbook seems to be very weak in terms of the development level of secularism.

In the eighth- grade Turkish Republic reforming history and Kemalism teacher guidebooks (Ataş, 2017), (Başol et al., 2017), the concept of secularism was used at the level of reinforcement. When the social studies curriculum (4-7) published by the Ministry of National Education (2017a) is examined in terms of standards, it is determined that the concept of secularism is not directly given. Again in the Turkish Republic reforming history and Kemalism Teaching Program published by the Ministry of National Education (2017b), it has been determined that expressions aiming to standards, the concept of secularism are not included in this program.

If the purpose and purpose of this study are to be mentioned, In Siirt province, it is known that there are around 60 religious schools operating outside the Tillo Medressehs (theological school attached to a mosque) and there are sects (Keser \& Seyidoğlu, 2017). Since the people living in this city have a generally conservative way of life, it would be interesting to see how students as part of the community perceive the concept of secularism. In addition, the place of secularism in curriculum and textbooks and the investigation of the teaching level of secularism constitute another component of this study.

The purpose of this study is; it is to examine how students perceive the concept of secularism, which they acquired through social studies lessons, through metaphor. At the same time, In 
the curriculum and social studies books, the concept of secularism; level, standards, spiral structure, and the subject of this concept will be examined in relation to each other. Another aim is to try to minimize the shortcomings that are obtained as a result of this the examined. In addition to this, the other questions that need to be answered are:

1- What is the relationship between the definition and structure of secularism and the metaphors that students create?

2- Among the metaphors created by students, what is the proportion of students who place extreme points on the concept of secularism?

3- Metaphors obtained from students, in which category and at what rate was collected; these collected categories will be evaluated according to the definition of the concept of secularism.

\section{Methodology}

\section{Research Pattern}

In this study, a descriptive survey model was used. Descriptive survey research is generally called researches on larger subjects than on other studies, in which characteristics such as a subject or interest, ability, attitude are identified (Büyüköztürk, Çakmak et al., 2014). According to Karakaya (2014), it is a research used in social sciences which are used widely on large groups, in which individuals' opinions about facts and events, their attitudes, facts, and events are described. Again, according to Robson (2017), it is necessary to collect data in a standard form with a relatively large number of individuals in descriptive survey research and to select individuals who represent the universe. In this study, metaphor applied to students as stated in the definition of descriptive survey research; the opinions, interests, and attitudes of the students in an indirect way towards the concept of secularism were searched.

\section{Study Group}

The study group consisted of the secondary school students enrolled in two secondary schools located in Siirt city center in the middle of the second semester of the academic year of 2016-2017. The prepared forms was applied to 155 students. In determining the sample, 
convenience sampling was utilized from non-random sampling methods (Büyüköztürk et al. 2014). The data on the study group are shown in Table 1.

Table 1

The Frequency and Proportional Distribution of the Students in the Study Group Based on the Grades they are Enrolled and their Gender

\begin{tabular}{lcccccc}
\hline & \multicolumn{2}{c}{ Male } & \multicolumn{2}{c}{ Gender } & \multicolumn{2}{c}{ Total } \\
Section & $\begin{array}{c}\text { Frequency } \\
\text { (f) }\end{array}$ & Ratio (\%) & $\begin{array}{c}\text { Frequency } \\
\text { (f) }\end{array}$ & Ratio (\%) & $\begin{array}{c}\text { Frequency } \\
\text { (f) }\end{array}$ & Ratio (\%) \\
\hline $5^{\text {th }}$ Grade & 23 & 57,5 & 17 & 42,5 & 40 & 26 \\
$6^{\text {th }}$ Grade & 26 & 65 & 14 & 35 & 40 & 26 \\
$7^{\text {th }}$ Grade & 23 & 62 & 14 & 38 & 37 & 24 \\
$8^{\text {th }}$ Grade & 16 & 42 & 22 & 58 & 38 & 24 \\
Total & 88 & 57 & 67 & 43 & 155 & 100 \\
\hline
\end{tabular}

Out of 155 students making up the study group, 88 (57\%) were males and 67 (43\%) were females and their distributions within the classes themselves were respectively; $5^{\text {th }}$ grade $(26 \%), 6^{\text {th }}$ grade $(26 \%), 7^{\text {th }}$ grade $(24 \%)$ and $8^{\text {th }}$ grade $(24 \%)$. Excluding the $8^{\text {th }}$ grade, the number of girls was lower than that of the boys.

Table 2

From The Study Group, The Frequency and The Proportional Distributions of The Students Who Answer The Forms and didn't Answer According to The Classes They are Situated

\begin{tabular}{|c|c|c|c|c|c|c|}
\hline \multirow{2}{*}{ Section } & \multicolumn{2}{|c|}{ Responding } & \multicolumn{2}{|c|}{ Nonresponding } & \multicolumn{2}{|c|}{ Total } \\
\hline & $\begin{array}{c}\text { Frequency } \\
\text { (f) }\end{array}$ & Ratio (\%) & $\begin{array}{c}\text { Frequency } \\
\text { (f) }\end{array}$ & Ratio (\%) & $\begin{array}{c}\text { Frequency } \\
\text { (f) }\end{array}$ & Ratio (\%) \\
\hline $5^{\text {th }}$ Grade & 17 & 42,5 & 23 & 47,5 & 40 & 26,5 \\
\hline $6^{\text {th }}$ Grade & 24 & 60 & 16 & 40 & 40 & 26,5 \\
\hline $7^{\text {th }}$ Grade & 20 & 54 & 17 & 46 & 37 & 23 \\
\hline $8^{\text {th }}$ Grade & 19 & 50 & 19 & 50 & 38 & 24 \\
\hline Total & 80 & 52 & 75 & 48 & 155 & 100 \\
\hline
\end{tabular}


Out of 155 students who made up the study group, $80(52 \%)$ answered the secularism forms and $75(48 \%)$ did not answer the forms. Considering the students who answered the forms and who did not answer it based on their class, the $6^{\text {th }}$ grade was the class with highest responding rate scoring $24(60 \%)$ and the $5^{\text {th }}$ grade was the class with the lowest responding rate scoring $17(42.5 \%)$. Considering the ratios of the nonresponding students, the $8^{\text {th }}$ grade had the highest ratio scoring $19(50 \%)$ and the $6^{\text {th }}$ grade had the lowest ratio scoring 16 $(40 \%)$.

\section{Data Collection}

A form, which included the statement 'secularism is similar to .......because......', in order to determine the perception of the secondary school students in Siirt city center about the concept of secularism. It was explained that metaphors, i. e. resemblance, could be made by anything (tangible, intangible, living and unloving beings) and the students were asked to write the reasoning for the metaphor in the 'because...' section. The participants were allowed in the classroom a 10 minute period for relaying their thoughts by focusing only on one metaphor. These forms were filled by the students and make up the fundamental data source of this research as a document.

\section{Data Analysis and Interpretation}

The qualitative data derived at the end of the study were resolved according to the content analysis. The content analysis aimed to acquire the concepts and relationships that could explain the collected data. The primary procedure carried out in the content analysis was to combine the similar data in the framework of specific concepts and themes and to organize and interpret them in a fashion for the readers to comprehend them (Y1ldırım \& Şimşek, 2013).

The data derived from the study group were analyzed in five stages as (1) coding and sorting, (2) compilation of sample metaphors, (3) category development, (4) validity and reliability and (5) sending the data to the computer environment (Saban, 2009; Coşkun, 2010). The studies conducted on this issue are given below. 
Coding and Sorting Stage: 155 forms were distributed to the students. 75 of the 155 students surveyed are using the expressions and signs such as "?", "What is this!", "I do not know this" on these forms they answer when they do the sex and class coding on the form. 80 of the 155 students were able to produce a metaphor for the concept of secularism. These metaphors produced are numbered again by the researcher. In short, in this research, while the concept of secularism was evaluated over 155 students, categorization was carried out using the metaphors obtained from 80 students.

The Example Metaphor Compilation Stage: The metaphors listed in this stage were reviewed and an example metaphor statement representing each metaphor was selected from the forms filled by the students. The purpose was to improve the validity of the analysis process and interpretations by using these data.

The Category Improvement Stage: The conceptualization of the 'secularism' phenomena of each metaphor image by the students was studied based on 80 metaphors formed by the students. Moreover, the metaphors formed by the students were studied in terms of their attributes about the 'secularism' concept. In order to generate a category, the metaphors that were formed by the students were grouped based on their subject and explanations. The relationship of the metaphors within themselves and between the groups was analyzed and five conceptual categories were generated.

The Validity and Reliability Stage: To achieve reliability, the list consisting of 80 metaphors and the list consisting of 5 conceptual categories were submitted to experts and he was asked to match the first list with the second list. The list generated by the experts and the list generated by the researcher were compared and their identities and differences were determined and then the reliability of the study was estimated with the formula of Miles and Hubermann (1994) 'Reliability= (opinion identity): (opinion identity + opinion difference $) x$ $100^{\prime}$. It was seen that the experts related the 6 metaphors with different categories. In the reliability analysis made accordingly, the study reliability was estimated as 0.92 .5 . The procedure is formulated as follows:

$$
[\text { Reliability }=((74):(74+6)) \times 100=\text { Reliability }=0,92.5]
$$


In qualitative studies, the desired reliability level is achieved when the conformity between the expert's and researcher's assessments is 0,90 and higher (Saban, 2008).

The Stage of Sending the Data to the Computer Environment: All data were sent to the computer environment and the number of participants (f) representing the 80 metaphors and 5 conceptual categories and their ratio (\%) were estimated.

\section{Findings}

In the results section, the metaphors developed by the students about the 'secularism' concept with the forms and the 5 categories generated based on these metaphors were supported by the example statements developed by the students.

\section{The Metaphors about the 'Secularism' Concept}

The metaphors generated about the 'secularism' concept by the students are shown in Table 3.

Table 3

The Metaphors generated by the Students about the 'Secularism' Concept and the Number of the Students Representing them and their Percentages

\begin{tabular}{|c|c|c|c|c|c|c|c|c|}
\hline Item & $\begin{array}{l}\text { Generated } \\
\text { Metaphors }\end{array}$ & 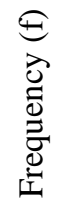 & Item & $\begin{array}{l}\text { Generated } \\
\text { Metaphors }\end{array}$ & 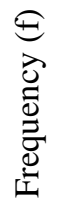 & Item & $\begin{array}{l}\text { Generated } \\
\text { Metaphors }\end{array}$ & 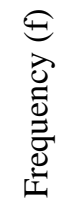 \\
\hline 1 & Religion & 9 & 16 & Atheism & 1 & 31 & Republic & 1 \\
\hline 2 & State & 6 & 17 & Arasat & 1 & 32 & National & 1 \\
\hline 3 & Innovation & 6 & 18 & Religion & 1 & 33 & Independence & 1 \\
\hline 4 & Right & 5 & 19 & Respect & 1 & 34 & World & 1 \\
\hline 5 & Equity & 5 & 20 & Constitution & 1 & 35 & Society & 1 \\
\hline 6 & Justice & 3 & 21 & Renovation & 1 & 36 & Islam & 1 \\
\hline 7 & Friendship & 3 & 22 & Family bond & 1 & 37 & Nationality & 1 \\
\hline 8 & Law & 2 & 23 & Technology & 1 & 38 & Turkey & 1 \\
\hline 9 & Country & 2 & 24 & Good manners & 1 & 39 & Separator & 1 \\
\hline 10 & Peace & 2 & 25 & Willpower & 1 & 40 & A clock & 1 \\
\hline 11 & Education & 2 & 26 & Liberty & 1 & 41 & Mind & 1 \\
\hline 12 & Separation & 2 & 27 & Atatürk & 1 & 42 & Unity & 1 \\
\hline 13 & Democracy & 2 & 28 & Brotherhood & 1 & 43 & Presidency & 1 \\
\hline 14 & Social Studies & 2 & 29 & Human & 1 & & TOTAL & 80 \\
\hline 15 & Home country & 1 & 30 & Election & 1 & & & \\
\hline
\end{tabular}


Table 3 shows that the frequencies were between 2 and 9 of 14 metaphors from 43 metaphors, and 29 metaphors have been a frequency. A total of 80 metaphors were generated by students.

The students formed the following metaphors the most; Religion $(f=9)$, state $(f=6)$, innovation $(\mathrm{f}=6)$, right $(\mathrm{f}=5)$, equity $(\mathrm{f}=5)$, justice $(\mathrm{f}=3)$, friendship $(\mathrm{f}=3)$; law, country, peace, education, separation, democracy, social studies $(\mathrm{f}=2)$.

\section{The Distribution of Metaphors about the Concept of 'Secularism' based on the Categories}

The concept of secularism expresses the separation of religion and state affairs by improving the scope of politics, law, and religion in time and the mind is dominant in the social, political, economic and legal order of the state (Akb1yık, 2001). While the categories were being created, the metaphors created by the students and their explanations have been taken into consideration. With regard to the concept of secularism, the above explanations show that the identity with made together with the formation of the categories are compatible with each other.

Considering the metaphors of the students about the concept of 'secularism' based on the categories, there are 5 categories as in terms of 'politics and administration, social and cultural, religion, law and belonging (Table 4). There are also common metaphors included in more than one category, and these are state and right metaphors.

\section{Table 4}

The Metaphor Categories Formed by the Students about the Concept of 'Secularism'

\begin{tabular}{|c|c|c|c|c|c|}
\hline \multirow[b]{2}{*}{ Item } & \multirow[b]{2}{*}{ Categories } & \multirow[b]{2}{*}{ Metaphor Names } & \multirow[b]{2}{*}{ Metaphor } & \multicolumn{2}{|c|}{ Metaphor } \\
\hline & & & & $\begin{array}{l}\text { Frequency } \\
\text { (f) }\end{array}$ & $\begin{array}{l}\text { Ratio } \\
(\%)\end{array}$ \\
\hline 1 & $\begin{array}{l}\text { Politically and } \\
\text { administratively }\end{array}$ & $\begin{array}{l}\text { Liberty, independence, presidency, State, } \\
\text { democracy, separation, separator, respect, } \\
\text { country, family bonds, a clock, peace. }\end{array}$ & 12 & 20 & 25 \\
\hline 2 & $\begin{array}{l}\text { Socially and } \\
\text { culturally }\end{array}$ & $\begin{array}{l}\text { Election, republic, world, unity, good } \\
\text { manners, education, renovation, }\end{array}$ & 16 & 28 & 35 \\
\hline
\end{tabular}




\begin{tabular}{|c|c|c|c|c|c|}
\hline \multirow[b]{2}{*}{ Item } & \multirow[b]{2}{*}{ Categories } & \multirow[b]{2}{*}{ Metaphor Names } & \multirow[b]{2}{*}{ Metaphor } & \multicolumn{2}{|c|}{ Metaphor } \\
\hline & & & & $\begin{array}{l}\text { Frequency } \\
\text { (f) }\end{array}$ & $\begin{array}{l}\text { Ratio } \\
(\%)\end{array}$ \\
\hline & & $\begin{array}{l}\text { innovation, technology, mind, brotherhood, } \\
\text { friendship, state, national, equity, Atatürk. }\end{array}$ & & & \\
\hline 3 & $\begin{array}{l}\text { In terms of } \\
\text { religion }\end{array}$ & Religion, atheism, Islam, human, religion. & 5 & 13 & 16 \\
\hline 4 & In terms of law & Constitution, justice, arasat, right, law. & 5 & 10 & 13 \\
\hline 5 & $\begin{array}{l}\text { In terms of } \\
\text { belonging }\end{array}$ & $\begin{array}{l}\text { Willpower, Turkey, Nationality, right, } \\
\text { society, Social studies, home country. }\end{array}$ & 7 & 9 & 11 \\
\hline & & Total & 45 & 80 & 100 \\
\hline
\end{tabular}

\section{The Categories for the Concept of 'Secularism'}

\section{Politically and Administratively}

The students prioritized the secularism concept in this category as political and administrative metaphors. The metaphors included in this category are; liberty $(f=1)$, independence $(f=1)$, presidency $(\mathrm{f}=1)$, state $(\mathrm{f}=5)$, Democracy $(\mathrm{f}=2)$, separation $(\mathrm{f}=2)$, separator $(\mathrm{f}=1)$, respect $(\mathrm{f}=1)$, country $(\mathrm{f}=2)$, family bonds $(\mathrm{f}=1)$, a clock $(\mathrm{f}=1)$ and peace $(\mathrm{f}=2) .12$ metaphors formed by 20 students were included for the generation of this category. These metaphors contain a $25 \%$ ratio within the total metaphors. The metaphor examples of this category are as follows:

"Secularism resembles the state because it is mandatory that there must be secularism in the state."

"Secularism resembles separation because the religion and state affairs are separate."

"Secularism resembles the state because the state does not discriminate against the public."

"Secularism resembles respect because respect is so important for the state as much as it is important for the people."

"Secularism resembles democracy because secularism improves democracy".

"Secularism resembles liberty because secularism is liberty."

"Secularism resembles the separator because it separates the religion and state affairs from each other." 
"Secularism resembles the state because secularism is in trust of the state." "Secularism resembles separation because it is the ruling of the religion and the state separately."

"Secularism resembles family bonds because if these bonds are broken nothing withstands. The state should protect these bonds."

"Secularism resembles peace because secularism brings peace to the country." "Secularism resembles a clock because the state should keep the religion and politics separately like the hour-hand and minute-hand."

\section{Socially and Culturally}

16 metaphors that are united socially and culturally are included in this category. These are election ( $\mathrm{f}=1$ ), Republic ( $\mathrm{f}=1)$, world $(\mathrm{f}=1)$, unity $(\mathrm{f}=1)$, good manners $(\mathrm{f}=1)$, Education $(\mathrm{f}=2)$, renovation $(\mathrm{f}=6)$, innovation $(\mathrm{f}=1)$, Technology $(\mathrm{f}=1)$, mind $(\mathrm{f}=1)$, brotherhood $(\mathrm{f}=1)$, friendship ( $\mathrm{f}=3$ ), state $(\mathrm{f}=1)$, national $(\mathrm{f}=1)$, Equity $(\mathrm{f}=5)$ and Atatürk $(\mathrm{f}=1)$. This category included 28 students. Its ratio to the total metaphors is $35 \%$. The example metaphors are as follows:

"Secularism resembles the Republic because it is a principle of Atatürk."

"Secularism resembles the nation because secularism is national".

"Secularism resembles the mind because Atatürk was smart. It is one of his principles."

"Secularism resembles the unity because secularism has caused the unity".

"Secularism resembles the world because there is unity in the world like there is unity in secularism".

"Secularism resembles friendship because friendship does not discriminate against religion".

"Secularism resembles good manners because a person is secular as much as he/she has good manners".

"Secularism resembles equity because when they say secularism I recall equity first".

"Secularism resembles equity because equity equals secularism." 
"Secularism resembles Atatürk because secularism is one of Atatürk principles". "Secularism resembles brotherhood because secularism improves brotherhood senses".

"Secularism resembles elections because we reach our own decision like in an election. People can be secular as well”.

"Secularism resembles equity because it is against discrimination".

\section{In Terms of Religion}

In this category, there are 5 metaphors prioritizing secularism in terms of religion. These are religion ( $\mathrm{f}=9$ ), atheism $(\mathrm{f}=1)$, Islam $(\mathrm{f}=1)$, people $(\mathrm{f}=1)$ and religion $(\mathrm{f}=1)$. These metaphors were formed by 13 students. Its ratio to the total metaphor is $16 \%$. The example metaphors are as follows:

"Secularism resembles Islam because Islam respects everyone's religion".

"Secularism resembles religion because secularism is a principle respecting everyone's religion."

"Secularism resembles religious affairs because religious affairs should deal with religion”.

"Secularism resembles atheism because religion and state affairs are separated by secularism."

"Secularism resembles people because people have privacy like religion is private. They live as they wish."

\section{In Terms of Legally}

In this category, metaphors emphasizing the secularism concept were formed by 10 students. The ratio of this metaphor to the other categories is $13 \%$. These metaphors are as follows: Constitution ( $\mathrm{f}=1)$, justice $(\mathrm{f}=3)$, Arasat $(\mathrm{f}=1)$, right $(\mathrm{f}=3)$, law $(\mathrm{f}=2)$. The example metaphors about this category are given below:

"Secularism resembles law because it is like the Sun within the law."

"Secularism resembles justice because secularism is just." 
"Secularism resembles friendship because we are all friends. We don't discriminate against religion and race."

"Secularism resembles justice because there is secularism within justice."

"Secularism resembles Constitution because it has a crucial place within our Constitution”.

"Secularism resembles arasat because religion and state affairs in law should be separate like the Heaven and Hell."

"Secularism resembles the right because it is our legal right."

\section{In Terms of Belonging}

A total of 7 metaphors formed by 9 students are about the secularism concept consisting of belonging and the ratio of these metaphors to the total metaphors is $11 \%$. In this category, the following metaphors were formed by the students; willpower $(\mathrm{f}=1)$, Turkey $(\mathrm{f}=1)$, nationalism $(\mathrm{f}=1)$, right $(\mathrm{f}=2)$, society $(\mathrm{f}=1)$, Social sciences $(\mathrm{f}=2)$ and home country $(\mathrm{f}=1)$. The metaphor examples of this category are as follows:

"Secularism resembles the society because it belongs to the society."

"Secularism resembles rights because we deserve rights."

"Secularism resembles rights because we have rights."

"Secularism resembles nationalism because nationalism must be secular."

"Secularism resembles willpower because willpower belongs to people and secularism belongs to the state."

"Secularism resembles home country because there is secularism in my country." "Secularism resembles social studies class because I learned about it for the first time in this class."

"Secularism resembles social studies because I learned about this subject in the 5th grade first. Therefore, it reminds me of it."

"Secularism resembles Turkey because Turkey is secular." 


\section{Discussion and Conclusion}

When the concept of secularism is examined in the programs and social books, secularism should be given at the beginner level to the fifth-grade students, it is seen that the concept of secularism is not mentioned in this book. While the concept of secularism is not directly included in the fifth-grade textbook, the secularism subjects in the sixth-grade textbook are likely to difficult students' concept acquisition. According to the fifth and sixth-grade social studies textbooks of the seventh-grade social studies textbook seems to have been prepared the concept of secularism in more accordance with the student level. It has been seen that the worksheets and workbooks in the social studies book are very weak in terms of secularism. In the standards determined according to the classes in the programs, the absence of the concept of secularism has been regarded as a deficiency.

Considering the ratios of the categories on secularism, it was uncovered that the ratio was $35 \%$ socially and culturally, $25 \%$ politically and administratively, $16 \%$ in terms of religion, $13 \%$ legally and $11 \%$ in terms of belonging. Considering these, it is seen that secularism was dealt with socially and culturally and politically and administratively the most and it was dealt with in terms of law and belonging the least. Based on these data, it is assessed positively that the students categorized the secularism concept socially and culturally and politically and administratively the most considering the definition and structure of the concept.

Socio-cultural and Political- administrative are seen to be the most expressed with $60 \%$ among metaphor categories. Even when evaluated only with these categories, it is seen that students have an understanding of secularism. In his study, Arthur (2009) states that secularism has become increasingly understood, while secularism is not fully aligned with socio-political philosophy, boundaries between them are largely in harmony with each other and this harmony is strictly aimed at creating public awareness in people.

Gökdeniz (2016) purported in his work titled "Religion and Conscience Liberty" that people should not be judged in terms of religion and conscience and they must be respected. Considering that the secularism must be $16 \%$ in the secularism category and considering the 
student opinions in the context of religion and conscience, it is seen that the data support this opinion.

In the study of Öztaş (2016) titled 'The Outlook on the Secularism Concept of the Printed Press in Turkey', it was aimed to analyze the outlook to the secularism in the conceptual secularism discussions based on columns of the primary national newspapers published in Turkey. It was stated in this study that there were two principal discussion areas were formed, namely tolerant and strict in the macro analysis discussions for the meaning of secularism in the newspapers, and the tolerant headings prioritized liberty, liberalism, democracy, and pluralism as a value. Excluding the liberalism, the students used the liberty, democracy and pluralism expressions the most and it resembled the above-stated study.

Out of 155 students making up the study group, 80 students (52\%) answered the forms and 75 students (48\%) did not answer the forms. Nearly $50 \%$ of the students did not answer the forms and this showed that the students did not adopt the concepts related with secularism adequately. Considering the forms, it was uncovered that there were expressions on the forms such as "?", "what is this?" and "I know about it"...generally.

Considering the ratio between the students who answered in the class basis and the students who did not answer, it is seen that the $6^{\text {th }}$ grade answered the most scoring $24(60 \%)$ and the $5^{\text {th }}$ grade answered the least scoring $17(42.5 \%)$. Considering the ratios among the students who did not answer, the $8^{\text {th }}$ grade had the highest ratio with $19(50 \%)$ and the $6^{\text {th }}$ grade had the lowest ratio with 16 (40\%). It was exhibited that despite the concept of secularism was at the reinforcement level for the $8^{\text {th }}$ graders, the least number of responses to the form was unexpected.

Students can perceive this concept differently, for secularism is an abstract concept. Therefore, it is necessary to pay attention to the teaching of this concept, especially considering the difficulty of learning the abstract concepts of the students in the elementary school age (Ulusoy, 2010). It is seen that the majority of the students who answered the form adapted the concept of secularism and the negative opinion of a student was included as well namely "secularism resembles atheism because religious affairs and state affairs are separated from each other by secularism". This student's view shows the existence 
misconception about secularism. Grigoriadis (2009) states that the term 'secular' in Turkey is viewed not only as a separation of religion and state affairs but also as "irreligion" among masses. It would be wrong to see this misconception only in Turkey. Hart (2016), for instance, states that when discussing today's use of the word of secularism, secularism can sometimes be considered sociological subversion of religious sanctity.

\section{Suggestions}

1. The concepts of secularism should be added to the fifth grade social studies the textbooks and workbooks

2. The sixth grade social studies textbook should be revisited according to the level of students acquiring the concept of secularism.

3. The concepts of secularism in fifth, sixth and seventh-grade social studies textbooks should be harmonized with each other. Any discrepancies, if any, should be removed.

4. New standards regarding the concept of secularism (especially for students in 7 th and 8th grades) should be established in Social Studies and the Turkish Republic Reforming History and Kemalism Curriculums.

5. The concept of secularism has been found as being weak in Social Studies workbooks (especially in the 7th grade) in terms of students' concept acquisition. The elimination of this deficiency will facilitate the acquisition of this concept and reduce the likelihood of the conceptual confusion.

6. In particular, more abstract concepts such as the concept of secularism should be considered as a whole in textbooks. 


\section{References}

Akbıyık, Y. (2001). Laiklik. Abant İzzet Baysal Üniversitesi Ĕgitim Fakültesi Dergisi, 1(2), 181- 192.

Akgün, S. K., (2006). Halifeliğin kaldırılması ve laiklik. (2. Edition), İstanbul: Temel.

Albayrak, H. Ş. (2015). Batı ülkelerinde din-devlet ilişkilerindeki alternatif modeller ve Türkiye örneği. Marmara Üniversitesi Ilahiyat Fakültesi Dergisi, 48(488), 185-198.

Arthur, J. (2009) Secularisation, secularism and catholic education: understanding the challenges, International Studies in Catholic Education, 1:2, 228-239, DOI: 10.1080/19422530903138226

Ataş, Ç. (2017). İlkögrretim 8. sınıf T.C. inkılâp tarihi ve Atatürkçülük öğretmen kılavuz kitabl. Ankara: Top.

Başol, S., Yıldırım, T., Koyuncu, M., Yıldız, A., Evirgen, Ö. F. (2017). İlköğretim Türkiye Cumhuriyet inkılap tarihi ve Atatürkçülük 8 ögretmen kılavuz kitabı. Mehmet Saray (Ed.). Ankara: MEB.

Bilgili, A. S. (2016). Sosyal Bilgiler Öğretim Programı. Ali S. Bilgili (Ed.). Sosyal Bilgilerin Temelleri (pp.35- 59). Ankara: Pegem.

Büyüköztürk, Ş., Çakmak, E. K., Akgün, Ö. E., Karadeniz, Ş. \& Demirel, F. (2014). Bilimsel araştırma yöntemleri (18. Baskı). Ankara: Pegem.

Çoşkun, M. (2010). Lise öğrencilerinin 'iklim' kavramıyla ilgili zihinsel imgeleri (metaforlar1). Turkish Studies, 5(3), 919.

Gişi, E. (2015). Laiklik kavramının kronolojik evrimi. The Journal of Europe-Middle East Social Science Studies, 1(1).

Gökdeniz, K. (2016). Din ve vicdan özgürlüğ̈̈; Padovalımarsilius'tan modern hukuk devletine kavramın içeriği. Journal of International Social Research, 9(44), 10741083.

Grigoriadis, I. N. (2009). Islam and Democratization in Turkey: secularism and trust in a divided society, Democratization, 16:6, 1194-1213, DOI: $10.1080 / 13510340903271803$

Dinçkol, B. (2002). Türkiye'de Anayasal Düzen ve Laiklik. Retrieved, June, 02, 2017, from http://acikerisim.ticaret.edu.tr:8080/xmlui/bitstream/handle/11467/130/Bihterin\%20D in $\%$ C4\%93kol.pdf?sequence $=1$ 
Ertan, T. F. (2007). Türkiye Cumhuriyeti Anayasalarında Laiklik. Ankara Üniversitesi Türk Inkılâp Tarihi Enstitüsü Atatürk Yolu Dergisi, 39, 409-423.

Evirgen, Ö. F., Özkan, J., Öztürk, S., Özdural, Z. (2017). Ortaokul sosyal bilgiler 5. sınıf ders kitabı. İstanbul: Bilnet.

Hart, J. G. (2016). Deep secularism, faith, and spirit, International Journal of Philosophical Studies, 24:5, 639-662, DOI: 10.1080/09672559.2016.1249609

Kahraman, M. (2008). Avrupa Birliği Ülkelerinde ve Türkiye'de Laiklik/ Secularism in the European Union Countries and Turkey. Mustafa Kemal Üniversitesi Sosyal Bilimler Enstitüsü Dergisi, 5(9).

Karakaya, F. M., Midilli, A. \& Güven, M. N. (2017). Illköğretim sosyal bilgiler 6 ögretmen kllavuz kitabı. Ankara: Sevgi.

Karakaya, İ., (2014). Bilimsel araştırma yöntemleri. A. Tanrıöğen (Ed.), Bilimsel araştırma yöntemleri (pp.191-248) Ankara: An1.

Keser, İ. ve Seyidoğlu, S. (2017), Medrese ve otorite: Siirt Tillo medreseleri örneği, Türk ve İslam Dünyası Sosyal Araştırmalar Dergisi /The Journal Of Turk \& Islam World Social Studies, 4 (12), 8-17, Doi Number :http://dx.doi.org/10.16989/TIDSAD.1289

MEB (2017a). Sosyal Bilgiler Dersi Öğretim Programı. Ankara. Retrieved April, 03, .2018, from http://mufredat.meb.gov.tr/ProgramDetay.aspx?PID=354

MEB (2017b). T.C. İnkılâp Tarihi ve Atatürkçülük Dersi Öğretim Programı (Ortaokul 8. sinıf). Ankara. $\quad$ Retrived April, 03, 2018, from http://mufredat.meb.gov.tr/ProgramDetay.aspx?PID=355

Miles, M. B. \& Huberman, A. M. (1994). Qualitative data analysis: an expanded source book. (2. Edition), London: Sage.

Öztaş, F. (2016). Türkiye'de yazılı basının laiklik kavramına bakışı. Journal of Graduate School of Social Sciences, 20(4), 1201-1217.

Özturalı, İ. M., (1999). Türkiye'de laikliğin serüveni. (2. Edition), İstanbul: Toplumsal Dönüșüm.

Paker, K. T. \& Cesur, S. (2013). Laiklik konusunda ayrışan gruplar ve belirli psiko-sosyal değişkenlerin diş-grup değerlendirmelerinde rolü. Akademik Araştırmalar Dergisi, (57), 51.

Robson, C. (2017). Bilimsel araştırma yöntemleri gerçek dünya araştırması. (Ş. Çınkır \& N. Demirkasımoğlu, Trans. Edit.), (2. Edition), Ankara: Anı. 
Saban, A. (2009). Öğretmen adaylarının öğrenci kavramına ilişkin sahip oldukları zihinsel imgeler. Türk Ĕ̌itim Bilimleri Dergisi, 7 (2), 281-326.

Saray, M., (2006). Türklerde dini ve kültürel hoşgörü, Atatürk ve laiklik. Ankara: Atatürk Araştırma Merkezi.

Ulusoy, K. (2010). İlköğretim sosyal bilgiler öğretmen adaylarının laiklik kavramının öğretimi ile ilgili görüşleri. Milli Eğitim Dergisi, 40 (185), 300-313. Retrieved April, 26, 2018, from http://dergipark.gov.tr/milliegitim/issue/36199/407104

Ünal. F., Özdemir, H., Ünal, M. Evirgen, Ö. F., Dağ, Ö., Kutay, S. (2017). İlköğretim sosyal bilgiler 7 ögretmen kılavuz kitabı. Ankara: MEB.

Yıldırım, A. \& Şimşek, H. (2013). Sosyal bilimlerde araştırma yöntemleri. (9. Edition), Ankara: Seçkin. 